Jean-Philippe Bonjour*

\title{
The dietary protein, IGF-I, skeletal health axis
}

DOI 10.1515/hmbci-2016-0003

Received January 7, 2016; accepted February 12, 2016; previously published online March 17, 2016

\begin{abstract}
Dietary protein represents an important nutrient for bone health and thereby for the prevention of osteoporosis. Besides its role as a brick provider for building the organic matrix of skeletal tissues, dietary protein stimulates the production of the anabolic bone trophic factor IGF-I (insulin-like growth factor I). The liver is the main source of circulating IGF-I. During growth, protein undernutrition results in reduced bone mass and strength. Genetic defect impairing the production of IGF-I markedly reduces bone development in both length and width.
\end{abstract} The serum level of IGF-I markedly increases and then decreases during pubertal maturation in parallel with the change in bone growth and standing height velocity. The impact of physical activity on bone structure and strength is enhanced by increased dietary protein consumption. This synergism between these two important environmental factors can be observed in prepubertal boys, thus modifying the genetically determined bone growth trajectory. In anorexia nervosa, IGF-I is low as well as bone mineral mass. In selective protein undernutrition, there is a resistance to the exogenous bone anabolic effect of IGF-I. A series of animal experiments and human clinical trials underscore the positive effect of increased dietary intake of protein on calcium-phosphate economy and bone balance. On the contrary, the dietary protein-induced acidosis hypothesis of osteoporosis is not supported by several experimental and clinical studies. There is a direct effect of amino acids on the local production of IGF-I by osteoblastic cells. IGF-I is likely the main mediator of the positive effect of parathyroid hormone (PTH) on bone formation, thus explaining the reduction in fragility fractures as observed in PTH-treated postmenopausal women. In elderly women and men, relatively high protein intake protects against spinal and femoral bone loss. In hip fracture patients, isocaloric correction of the relatively low protein intake results in: increased IGF-I serum level, significant attenuation of postsurgical bone loss, improved

\footnotetext{
*Corresponding author: Jean-Philippe Bonjour, Professor, Division of Bone Diseases, Geneva University Hospitals and Faculty of Medicine, Rue Gabrielle Perret-Gentil 4, CH - 1211 Geneva 14, Switzerland, Phone: +4122 37299 50, Fax: +41 223829973 E-mail: jean-philippe.bonjour@unige.ch
}

muscle strength, better recovery, and shortened hospital stay. Thus, dietary protein contributes to bone health from early childhood to old age. An adequate intake of protein should be recommended in the prevention and treatment of osteoporosis.

Keywords: anorexia nervosa; bone acquisition; dietary protein; elderly; fragility fracture; IGF-I; osteoporosis; postmenopausal women.

\section{Historical aspects}

Two discoveries were essential for the development of our knowledge on the relation between insulin-like growth factor I (IGF-I) and dietary protein. First, the identification of IGF-I as a factor distinct from insulin. Second, the influence of dietary components on the production of IGF-I formerly and transiently also designated "somatomedin-C".

In 1963, Froesch and his colleagues discovered that the human serum contained an insulin-like activity that was nonsuppressible by insulin antibodies [1]. Moreover, in contrast to insulin, this activity was neither influenced by an overnight fast nor by an oral glucose load [1]. Between 1983 and 1985, dietary protein was recognized as an important macronutrient in the regulation of this insulin-like activity [2-4]. Before the publication of these key nutrition-related observations, Daughaday and his colleagues discovered that a serum biological activity increased the sulfate uptake in cartilaginous glycosaminoglycans [5]. Later on, these authors proposed to designate this sulfation factor by the term "somatomedin-C" [6]. Then, this factor was shown to be both structurally and biologically identical to IGF-I $[7,8]$. In human adults, variations in the serum level of somatomedin-C/IGF-I during fasting and refeeding were highly correlated with the nitrogen balance [2]. These early findings forecast that IGF-I will be shown to play a key role for increasing protein synthesis and decreasing protein degradation in many organs and tissues, particularly in skeletal muscle [9]. Measurement of somatomedin-C/IGF-I in serum was then demonstrated to be a means for monitoring the response of malnourished patients to nutritional intervention [4]. In clinical settings, serum IGF-I was a much more sensitive index of nutritional status than the concentrations of prealbumin, transferrin, and retinol-binding protein [4]. 
During the next two decades, the development of technical and clinical tools made it possible to appreciate that the dietary protein-IGF-I axis was an important nutritional-hormonal link in bone health and diseases [10]. This concept was experimentally documented in both animal model of osteoporosis [11, 12] and in hip fracture patients [13-15].

\section{Proteins in bone}

\section{Quantitative aspects}

A rough estimate of protein mass in bone would amount to $2.0 \mathrm{~kg}$ in a healthy adult man of $70 \mathrm{~kg}$ with average body mass index (BMI), taken as a classical reference model. In comparison, the total mass of protein contained in skeletal muscle is $5.0 \mathrm{~kg}$ [16]. Assuming that the protein mass corresponds to about $19 \%$ of body weight [17], the total mass of protein would amount to $13.3 \mathrm{~kg}$ for $70 \mathrm{~kg}$ b.w. The distribution of protein corresponds to $15 \%$ and $37.6 \%$ in bone and skeletal muscle, respectively. Thus, bone and skeletal muscle taken together contain more than $50 \%$ of total body proteins.

\section{Qualitative aspects}

Bone is a composite tissue made up of organic matrix, mineral water, and cells. Collagen type I represents about $98 \%$ of total bone proteins. Bone mineral, an impure form of hydroxyapatite, is located within and between collagen fibrils. The main non-collagenous proteins are osteocalcin, osteopontin, sialoprotein, and osteonectin [18]. In the process of bone modeling, mainly during growth, and remodeling during adulthood, the organic matrix is formed and resorbed. Molecular products of these two processes, particularly from type I collagen, are released into the systemic extracellular compartment. They can be chemically analyzed and used as markers of bone formation and resorption [19-21]. Other non-collagenic bone proteins such as tartrate-resistant acid phosphatase-5b, specific bone alkaline phosphatase, or osteocalcin are also released during the process of bone remodeling. They are detectable in the systemic extracellular compartment and are also used to estimate the rate of bone remodeling, as well as its changes in response to physical, pharmaceutical, or nutritional interventions [19-21].

Protein from food is required to promote bone formation. As for any other organs of the body, the synthesis of intracellular and extracellular bone protein and other nitrogen-containing compounds is dependent upon the supply of amino acids. Besides this role as "brick supplier", proteins, through their amino acid constituents, can influence bone mineral economy and metabolism. This influence is mediated, at least in part, by the production and action of IGF-I (see below).

\section{IGF-I production and action in relation to food intake}

IGF-I is a 70-amino acid residue single-chain polypeptide. It is expressed in most tissues of the body. Nevertheless, liver-produced IGF-I is the main source of circulating IGF-I $[22,23]$. Growth hormone (GH) is the principal hormonal stimulus of IGF-I. However, in food-restricted humans, GH secretion is not responsible for the decline in IGF-I production [24].

IGF-I acts through the IGF-I receptor (IGF-IR) which is a tyrosine kinase that activates several intracellular signaling pathways (for review see [22]). There is an apparent similarity of IGF-I and insulin receptor. However, activation of these two receptors results in distinct effects on gene expression and function [22]. IGF-I primarily stimulates growth and cell survival, whereas insulin controls carbohydrates, lipid, and protein metabolism. In contrast to IGF-I, IGF-II that binds to a receptor distinct from IGF-IR does not appear to have further postnatal effects on growth [25].

In dietary restriction such as fasting, the number of growth hormone receptors (GHRs) in the liver is decreased. This effect is associated with a reduction in the IGF-I gene expression. Nutritional deprivation impairs both transcriptional and post-transcriptional mechanisms that contribute to the decline in circulating IGF-I [26]. Diet restriction also enhances the clearance and degradation of serum IGF-I, two processes that add to the lowering of its circulating level [26]. In young rats, carcass growth is impaired under protein restriction despite normalization of serum IGF-I concentration by exogenous administration [27]. In adult rats, this resistance to the action of IGF-I under protein restriction was further documented at the bone cellular level [12]. Thus, protein restriction induced osteoblastic resistance to the action of administered rhIGF-I/IGFBP-3 complex, with failure to increase both cancellous and periosteal bone formation [12]. In response to variations in protein intake, the changes in circulating IGF-I can be observed in absence of any differences in the dietary supply of energy as observed in both rigorous 
experimental conditions in adult rats $[11,12]$ and in a randomized clinical trial in hip fracture patients [14].

\section{Dietary protein-IGF-I axis on bone mineral economy and metabolism}

Enhanced IGF-I production linked to food protein exerts a favorable impact on bone mineral economy by a dual renal action. IGF-I stimulates the kidney production and increases the circulating level of 1,25 dihydroxyvitamin D $(1,25 \mathrm{D})$ [28-31], the active form of vitamin D (Figure 1). This vitamin $\mathrm{D}$ metabolite in turn boosts the intestinal absorption of both calcium (Ca) and inorganic phosphate (Pi). The second action of IGF-I at the kidney level is to increase the tubular reabsorption of $\mathrm{Pi}$. Through this dual activity of IGF-I, the concentration of $\mathrm{Ca}$ and $\mathrm{Pi}$ in the systemic extracellular compartment rises and thereby positively influences the process of bone mineralization [33]. The indirect positive effect of protein intake on intestinal Ca absorption, via the IGF-I - 1,25D link, is combined with a direct stimulatory effect of amino acids such as arginine and lysine on Ca translocation from the luminal to

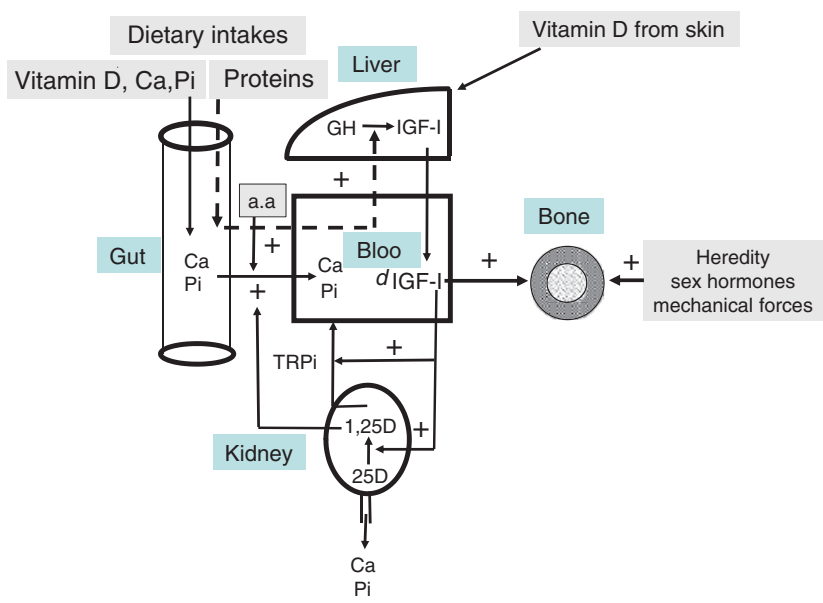

Figure 1: Role of dietary protein on Ca-Pi economy and bone health. The hepatic production of insulin-like growth factor-I (IGF-I), which is under the positive influence of the growth hormone (GH), is also stimulated by amino acids (a.a.). IGF-I exerts a direct action on bone anabolism. In addition, at the kidney level, IGF-I increases both 1,25 ,dihydroxyvitamin $D(1,25 \mathrm{D})$ formation from 25 -hydroxyvitamin $\mathrm{D}(25 \mathrm{D})$ and the tubular reabsorption (TR) of $\mathrm{Pi}$. By this dual renal action, IGF-I favors a positive balance of calcium and Pi. Moreover, a.a. can directly stimulate the intestinal absorption of calcium that can account for the increased urinary calcium excretion observed with high protein diet. 25D is formed in the liver from vitamin D, which is supplied from both dietary and cutaneous sources. Figure reproduced from reference [32]. the contraluminal side of the intestinal mucosa [34, 35] (Figure 1). Amino acids might activate the Ca-sensing receptors (CaRs) [36] and thereby increase the translocation of Ca through the channels (TRP)V5 and/or TRPV6 localized in the intestinal epithelium [37, 38] (for review see also [39-41]). Quantitatively, the enhanced intestinal $\mathrm{Ca}$ absorption to a large extent explains the associated calciuria. This quantitative matching makes it unlikely that a source other than gut would contribute to the dietary protein-induced increase in urinary Ca excretion $[42,43]$. This notion is corroborated by the fact that relatively high protein intake is not associated with a negative Ca balance [42, 43]. Furthermore, reduced intestinal Ca absorption and increased serum level of both parathyroid hormone (PTH) and 1,25D are observed when healthy women are exposed to a relatively low $(0.7 \mathrm{~g} / \mathrm{kg} /$ day $)$ as compared to medium $(1.0 \mathrm{~g} / \mathrm{kg} /$ day $)$ or high $(2.1 \mathrm{~g} / \mathrm{kg} /$ day $)$ protein diet $[44,45]$. By using Ca kinetics in human, there was no increase in bone resorption in response to a high protein diet inducing a marked elevation in both intestinal absorption and urinary excretion of $\mathrm{Ca}$ [35]. The net bone balance corresponding to the difference between bone resorption $\left(\mathrm{Vo}^{-}\right)$and bone formation $\left(\mathrm{Vo}^{+}\right)$was not reduced by the high protein diet [35]. Thus, a series of animal experiments and human clinical investigations underscore the positive effect of increased dietary intake of protein on Ca-Pi economy and bone balance.

In sharp contrast with the evidence described above, it has been alleged that dietary proteins, particularly those from animal sources, might be deleterious to bone health by inducing chronic metabolic acidosis eventually leading to osteoporosis. Over the last decades, this apparently attractive hypothesis has prompted several investigators to explore in epidemiologic studies whether consumption of high animal protein diet would be associated with either decreased areal bone mineral density (aBMD) or bone mineral content (BMC), or increased incidence of fragility fractures, particularly those occurring at the level of the proximal femur (see below). Nevertheless, several arguments have been raised against the dietary protein-induced acidosis hypothesis of osteoporosis [37, $43,46,47]$, a theory that disregards the essential homeostatic role of the kidney in the regulation of the acid-base balance [48]. Results from clinical investigation indicate that high protein diet induces neither a negative $\mathrm{Ca}$ balance nor acceleration in bone resorption rate [35, 49, 50]. The hypothesis that dietary protein, at an intake level leading to increased titratable acid and decreased $\mathrm{pH}$ in urine, would cause systemic acidosis and induce deleterious consequences on Ca economy and bone integrity has been refuted in several recent reviews and meta-analysis 
[37, 43, 46, 48, 51-53]. Furthermore, two other original reports did not sustain the hypothesis that high dietary acid load might be detrimental to bone by accelerating the age-related decline in aBMD and increase the incidence of fragility fracture $[54,55]$.

Furthermore, there is no consistent evidence for superiority of vegetal over animal protein on Ca metabolism and bone health. In fact, animal protein could be more efficacious than soy or vegetable protein for promoting bone growth in a laboratory animal model of skeletal development [56] or for preventing hip fracture in postmenopausal women [57].

\section{Local role of IGF-I at the bone level in response to amino acids and PTH}

There is direct evidence that amino acids such as arginine can stimulate the local production of IGF-I by osteoblastic cells [58]. This effect is associated with increased osteoblastic cell proliferation and collagen synthesis [58]. There is also evidence that IGF-I is the main mediator of the bone anabolic effect of PTH [59]. This PTH-IGF-I link explains, at least in part, the marked positive effect of intermittent PTH therapy on bone formation and bone mass as well as on fragility fracture reduction, as observed in a randomized controlled trial (RCT) carried out in osteoporotic women [60].

\section{Protein intake, IGF-I, and bone acquisition}

Bone mass and strength achieved by the end of the growth period, simply designated as "peak bone mass (PBM)", plays an essential part in the risk of osteoporotic fractures occurring in adulthood. It is considered that an increase in PBM by 1.0 standard deviation would reduce by $50 \%$ the fragility fracture risk (see for review [61]). The genetically determined trajectory of bone mass development can be, to a certain extent, modulated by modifiable environmental factors (Figure 2). Among these factors, physical activity and nutrition are key determinants in the acquisition of bone mass during growth. Growing bones are usually more responsive to mechanical loading [62] and bone trophic nutrients [61] than adult bones. Furthermore, the impact seems to be stronger before than during or after the period of pubertal maturation. Among nutrients that can specifically interact with bone metabolism, Ca supplementation has been extensively studied from infancy

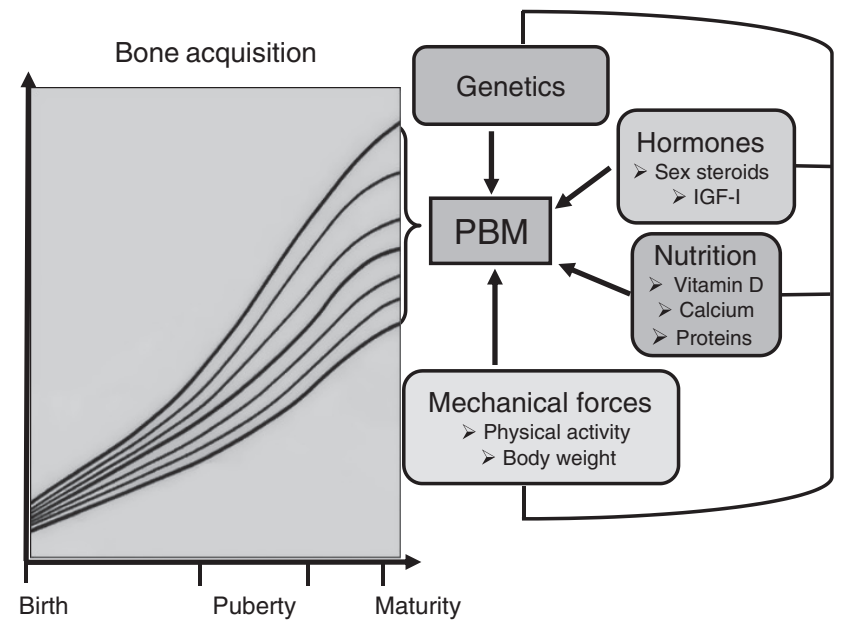

Figure 2: Determinants of bone mass and strength development from birth to maturity.

In healthy human subjects, four main determinants - genetics, hormones, nutrition, and mechanical forces - influence bone mass and strength from birth to the end of the second decade. At this time maximal value, the so-called peak bone mass (PBM) is virtually attained. As depicted on the right, these four factors are interconnected; for instance, an increased protein intake enhances the positive impact of physical activity on bone growth. The curves of the diagram on the left illustrate the wide range of individual PBM values that can be assessed at maturity among young healthy subjects of both genders. The genetically predetermined trajectory can be modified by environmental factors, particularly nutrition and physical activity. Figure reproduced from reference [32].

to the end of pubertal maturation. Much less consideration has been given to protein intake, although this macronutrient is essential for adequate accumulation of bone tissue during growth, as well as maintenance of the skeletal structural integrity throughout life.

Both animal and human studies indicate that low protein intake per se could particularly be detrimental to bone acquisition. Undernutrition, including inadequate supplies of energy and protein during growth, can severely impair bone development [63]. An inadequate protein supply appears to play a central role in the pathogenesis of the delayed skeletal growth and reduced bone mass that is observed in undernourished children [63]. Low protein intake could be detrimental to skeletal integrity by lowering the production of IGF-I [64]. Variations in the production of IGF-I could explain some of the changes in bone and Ca-Pi metabolism that have been observed in relation to dietary protein intake. Indeed, the plasma level of IGF-I is closely related to the growth rate of the body. In humans, circulating IGF-I progressively rises from 1 year of age to the onset of pubertal maturation. Then, serum IGF-I markedly increases to reach maximal values before declining toward adult values [65]. This pattern 
is in close correspondence to pubertal maturation, peak height velocity, and bone mass accumulation rate [65-67]. Among healthy individuals, there is a strong positive association between serum IGF-I and BMC accrual from early to mid-puberty [68]. As mentioned above, IGF-I appears to play a key role in Ca-Pi metabolism during growth by stimulating both the tubular Pi reabsorption and production of $1,25 \mathrm{D}$ at the kidney level [33]. Furthermore, IGF-I is considered as an essential factor for bone longitudinal growth, as it stimulates proliferation and differentiation of chondrocytes in the epiphyseal plate [69-71]. IGF-I also increases the external diameter of long bones, probably by enhancing the process of periosteal apposition [69-71]. Therefore, during adolescence, a relative deficiency in IGF-I or a resistance to its action may result in a reduction in both longitudinal and cross-sectional bone development [69-71].

In "well" nourished children and adolescents, the question arises whether or not variations in the protein intake within the "normal" range can influence skeletal growth and thereby modulate the influence of genetic determinants on PBM attainment [72]. Considering the relationship between protein intake and bone mass gain, it is not surprising to find a positive correlation between these two variables [72]. This association appears to be particularly significant in prepubertal children $[67,73]$.

\section{Interaction of protein intake and physical activity}

Growing bones are usually more responsive to mechanical loading than adult bones. Increased physical activity was shown to stimulate mineral mass accumulation in children and adolescents [74]. Adequate nutritional supply can be expected to sustain the anabolic effect of mechanical loading on bone tissue, as it does on skeletal muscle development. Among nutrients, high $\mathrm{Ca}$ intake was reported to enhance the response to physical activity in healthy children aged 3-5 years [75]. Long-term protein consumption exerts a stronger impact on bone mass and strength acquisition in healthy children and adolescents aged 6-18 years than Ca intake [76]. In prepubertal boys, high protein intake was shown to enhance the bone response to increased physical activity [77]. At the femoral neck level, the increased bone mass was associated with a wider external perimeter [77], a macroarchitecture feature that should confer greater resistance to mechanical load [78]. Of interest, this response tracks from prepuberty to mid-late puberty [79]. At this stage of sexual maturation in healthy boys, microstructural changes can be recorded that should provide greater strength to weight-bearing bones [79]. These results underscore the importance of protein intake to enhance the bone response to mechanical strain during growth. They strongly suggest that early intervention combining protein intake and physical exercise during childhood could induce protracted upward shift of the predetermined skeletal trajectory and thereby provide substantial benefit to adult bone health [79].

\section{Protein malnutrition and bone in relation with intensive exercise or anorexia nervosa}

\section{Intensive exercise}

A positive correlation between protein intake and bone mass has been found in premenopausal women [80]. In women on a low-calorie diet, insufficient protein intake could be particularly deleterious for bone mass integrity. In athletes or ballet dancers, intensive exercise can lead to hypothalamic dysfunction with delayed menarche and disruption of menstrual cyclicity and bone loss [81, 82]. In intensive exercise involved women, the combination of an eating disorder, menstrual dysfunction, and osteopenia has been called the "Female Athlete Triad" [83]. Nutritional restriction likely plays an important role in the disturbance of the female reproductive system resulting from intense physical activity. The propensity to nutritional restriction is more common when leanness confers an advantage for athletic performance. Insufficient energy intake with respect to energy expenditure is supposed to impair the secretion of GnRH and thereby leads to a state of hypoestrogenism. However, the relative contribution of insufficient protein intake with low IGF-I remains to be assessed, as it is frequently associated with reduced energy intake.

\section{Anorexia nervosa}

In young women, anorexia nervosa is a frequent condition [84-86]. Reduced aBMD can be measured at several skeletal sites in most women with anorexia nervosa [87]. It is not surprising that young women with anorexia nervosa are at increased risk of fracture later in life. Body weight, but not estrogen use, is a significant predictor of aBMD in women with anorexia nervosa [88]. With estrogen and 
Ca deficiency, low protein intake very likely contributes to the bone deficit observed in anorexia nervosa. Circulating IGF-I, a marker of protein nutrition $[24,89]$, is low in anorexia nervosa (Table 1) [90]. In this situation, serum osteocalcin and bone-specific alkaline phosphatase, two biochemical markers of bone formation, are significantly reduced [91]. In mature adolescents with anorexia nervosa, circulating IGF-I was linked to variations in the nutritional state and was the major correlate of bone formation markers [91].

Anorexia nervosa patients significantly over-reported energy, and probably protein intake [92], notwithstanding the unreported use of purging means such as vomiting and laxatives [93, 94]. Nevertheless, protein depletion associated with low lean body mass has been clearly identified in anorexia nervosa patients [95]. This finding is in agreement with the decreased serum level of IGF-I found in this disease (for recent reviews see $[96,97]$ ) as well as in experimental isocaloric protein depletion [12]. Refeeding anorexia nervosa patients with a diet of which $20 \%$ of energy was provided by protein significantly increases both lean body mass - when rightly calculated in absolute value and not related to body weight - and total body protein [95]. Thus, anorexia nervosa patients were shown to replenish total body protein during nutritional rehabilitation [95].

\section{Effects of high protein diet on $\mathrm{Ca}$ and bone metabolism during energy deficit}

Energy deficit (ED), from either reduced dietary intake or increased expenditure, is used to induce weight loss

Table 1: IGF-I and lumbar spine aBMD in anorexia nervosa.

\begin{tabular}{lrrl}
\hline & $\begin{array}{r}\text { Anorexia nervosa } \\
\mathrm{n}=\mathbf{3 4}\end{array}$ & $\begin{array}{r}\text { Controls } \\
\mathrm{n}=\mathbf{3 3}\end{array}$ & $\mathrm{p}$-Value \\
\hline Age, year & 15.9 & 15.0 & \\
$\mathrm{BMI}, \mathrm{kg} / \mathrm{m}^{2}$ & 16.6 & 22.3 & $\mathrm{p}<0.001$ \\
$\mathrm{IGF}-\mathrm{I}, \mathrm{ng} / \mathrm{mL}$ & 294 & 556 & $\mathrm{p}<0.001$ \\
$\mathrm{LS}$ aBMD, $\mathrm{mg} / \mathrm{cm}^{2}$ & 893 & 971 & $\mathrm{p}<0.001$ \\
LS aBMD, Z-score & -0.74 & +0.13 & $\mathrm{p}<0.001$ \\
\hline
\end{tabular}

The marked reduction in BMI and in serum IGF-I reflects the deficient nutritional status documented in a group of anorexicadolescent girls as compared to age-matched controls. The bone consequence of anorexia nervosa is expressed by a severe deficit in lumbar spine (LS) aBMD, -0.87 Z-score. P-Value: Statistical probability for difference between anorexic patients and control subjects. Adapted from reference [88]. in overweight or obese subjects [98]. Periods of ED due to intense physical activity can also be experienced by healthy, normal-weight individuals such as athletes or army trainees [99]. Fat mass loss by ED in overweight and/or obese individuals can also be detrimental to skeletal muscle mass and strength as well as to bone integrity. During ED, the adverse effect on skeletal muscle can be attenuated by high protein diet. There has been some concern whether high protein diet may aggravate ED-induced bone loss [100, 101]. This issue has recently been examined in a short-time study in young healthy adults [98]. Increasing the protein consumption from $0.8 \mathrm{~g} / \mathrm{kg}$ bw/day [Recommended Dietary Allowance (RDA)] to $2.4 \mathrm{~g} / \mathrm{kg}$ bw/day did not negatively affect Ca homeostasis and bone turnover [98]. This observation is in keeping with a long-term study in postmenopausal women with elevated BMI showing that a higher protein diet during weight reduction increases circulating IGF-I and attenuates total and trabecular bone loss at several skeletal sites including ultradistal radius, lumbar spine, and total hip [102].

See section on "Dietary protein-IGF-I axis on bone mineral economy and metabolism" against the hypothesis of a causal relationship between protein intake and systemic acidosis leading to increased bone resorption and eventually age-related osteoporosis.

\section{Epidemiological studies on protein intake in adult women and in the elderly}

An early small but often quoted cross-sectional study suggested that high protein diet might be detrimental to forearm aBMD in limited number of healthy young women [103]. However, in several later reports this negative association between protein intake and $\mathrm{BBMD}$ or BMC was not confirmed in both premenopausal and postmenopausal women. Furthermore, in a large number of studies, a positive relationship between protein intake and aBMD or BMC has been found (for review see $[37,46]$ ). In the Framingham Osteoporosis Study, increased protein intake was protective against spinal and femoral bone loss in a large cohort of elderly women and men prospectively followed over a period of 4 years [104]. As in hospitalized elderly patients, those with a higher protein intake had a greater aBMD, particularly at the femoral neck level [105]. Whereas a gradual decline in caloric intake with age can be considered as an adequate adjustment to the usual progressive reduction in energy expenditure, the parallel reduction in protein intake is certainly detrimental to 
both structure and function of several organs or systems including skeletal muscle and bone. With aging there is a decline in both the intake of protein (Figure $3 \mathrm{~A}$ ) and the circulating level of IGF-I (Figure 3B). As mentioned above, dietary protein is crucial for bone and muscle development. Recent evidence suggests a significant underestimation of protein requirements in adult human, particularly in elderly $[37,108,109,32]$. Thus, increasing protein above
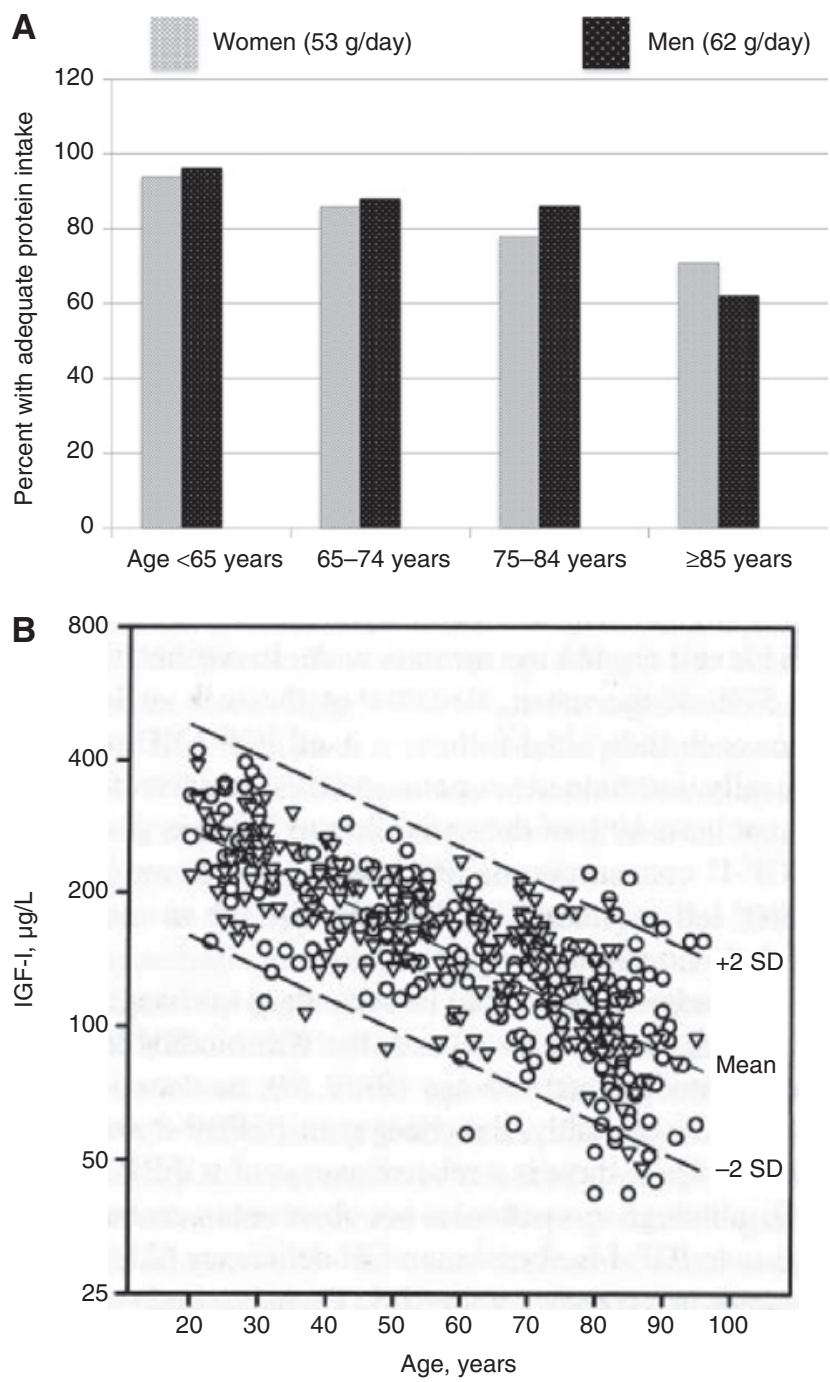

Figure 3: Protein intake, serum IGF-I in relation with aging. The decline with aging in the protein intake and in the serum level of IGF-I is depicted in A and B, respectively. (A) The protein consumption was recorded from a representative sample $(n=1453)$ of persons living in two Italian cities. The protein intake considered as adequate is indicated above the diagram for both women and men. Adapted from reference [106]. (B) The progressive decline in serum IGF-I was recorded in 448 healthy subjects from young adulthood to old age. The correlation coefficient R between IGF-I and age was $-0.74(p<0.01)$. The regression lines from the mean and 2 SD are shown. Women are represented by circles and men by triangles. Adapted from reference [107]. the RDA may help prevent the loss of bone and muscle mass in elderly [37, 108, 109, 32].

There is evidence suggesting that the favorable effect of increasing protein on aBMD or BMC is better sustained when the supply of both Ca and vitamin D is adequate [110-113]. Reciprocally, in postmenopausal women with low calcium intake (600 vs. $1500 \mathrm{mg} /$ day), a relatively high protein consumption ( $20 \%$ vs. $10 \%$ of energy intake) enhances Ca retention. Likewise, in healthy older women and men, protein supplements increasing the daily intake from 0.78 to $1.55 \mathrm{~g} / \mathrm{kg} / \mathrm{day}$, when isocalorically substituted to carbohydrates, were associated with higher circulating levels of IGF-I and lowered levels of urinary N-telopeptide, a marker of bone resorption [114]. These results are compatible with a preventive effect of relatively high protein intake on bone loss in elderly.

Recent reports from France [115], Canada [116], and the United States [117] sustain the notion that high rather than low protein intake is beneficial for musculoskeletal health in older adults.

The increased risk of mortality associated with low protein intake in the elderly has been suggested to be related to the increased need for dietary cysteine [118]. This amino acid supports the synthesis of glutathione, an oxidant scavenger and thereby a key protective factor that declines with aging [118]. Elderly patients hospitalized with hip fracture are often protein malnourished [119] and are at increased risk of mortality [120]. The relation between the specific need of dietary cysteine in proteinmalnourished hip fracture patients and the increased risk of mortality remains to be established.

\section{Cross-cultural comparison of hip fracture incidence}

Some cross-cultural studies comparing protein intake and hip fracture incidence in women living in various countries have been interpreted as suggesting that high protein intakes from animal source exert deleterious effects on bone health [121, 122]. However, the way both terms of this putative relationship between protein intake and hip fracture incidence were derived is highly questionable. First, the use of per capita food supplies provided by the FAO of the United Nations is not a reliable estimate of the protein intake of the population at risk of hip fracture. It is calculated from the total amount of animal protein available for the whole population, i.e. the amount produced plus the amount imported minus the amount exported by a given country, divided by the number of inhabitants. In this 
rough average estimate of the whole population intake, any selective decline in protein consumption with aging is not taken into account, as reported in several reviews $[37,111,119,123]$. Second, as expected, countries with the highest incidence of hip fracture are those with the longest life expectancy. Age adjustment to the 1977 or 1987 distribution of the US women population [121, 122] does not correct the marked difference in life expectancy between populations of various socio-economic conditions.

\section{Prospective observational studies on protein intake and hip fracture}

In contrast to this "negative" aspect of protein intake hypothesized from cross-cultural analysis, several prospective observational studies have rather shown either a protective effect of relatively high protein consumption or, at least, no detrimental effect on hip fracture incidence. Low protein intake has been documented in elderly subjects at risk of fragility fractures and more so in those experiencing hip fracture (for review see [119]). It is associated with low BMI as clearly documented in a meta-analysis gathering 12 prospective worldwide multicenter studies including 60,000 men and women with a total follow-up of 250,000 person-years [124]. In elderly, low BMI is correlated with protein undernutrition that, in turn, is associated with low bone and skeletal muscle mass [37, 123].

In a large prospective study (Iowa Women's Health Study) including about 32,000 women aged 55-69 years, total protein intake was inversely associated with the risk of hip fracture (Figure 4) [57]. Thus, the risk reduction in hip fracture incidence was $67 \%$ and $79 \%$ for the highest vs. the lowest quartile in total and animal protein intake, respectively [57]. In a smaller case-control study including both women and men residing in Utah, higher total protein intake was associated with a significant reduced risk of hip fracture in 50-69-year-old subjects [125]. In 70-89-year-old residents of this county, however, protein intake was not significantly associated with a decreased or an increased risk of hip fracture [125]. As discussed by the authors, it is unclear whether the lack of protective effect in the 70-89-year group would reflect a functional difference in nutritional protein metabolism or merely an artifact due to methodological limitations of the case-control study design in the oldest subjects [125]. In both Iowa and Utah studies, calcium intake did not modify the risk evaluation of hip fracture in relation with protein intake $[57,125]$. These observations somehow contrast with an

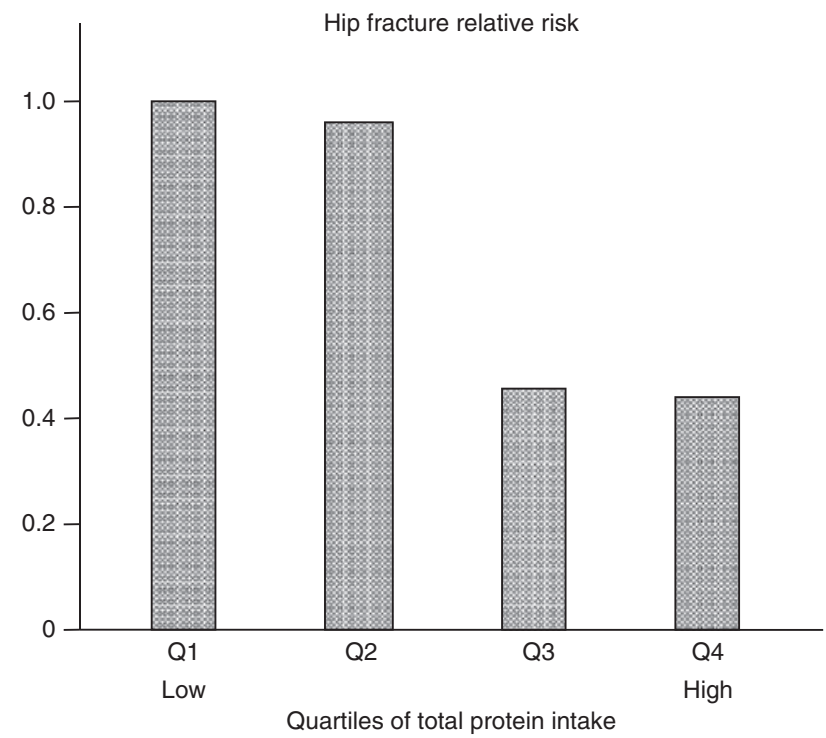

Figure 4: Reduced incidence of hip fracture with relatively high protein intake.

The diagram represents the relative risk of hip fracture according to quartiles of total protein intake. The nutrient intake was assessed in a cohort of lowa women aged 55-65 years at baseline. The incident hip fractures were ascertained in the follow-up analysis of 104,338 person-year. The risk of hip fracture was negatively associated with total protein intake (Q4>12.05 g/M) vs. Q1<9.56 g/M), age-adjusted relative risk: 0.31 ), especially from animal sources $(\mathrm{Q} 4>9.26 \mathrm{~g} / \mathrm{MJ}$ vs. Q1<6.48 g/MJ, age-adjusted relative risk: 0.21 ) after adjustment for age, body size, parity, smoking, alcohol intake, estrogen use, and physical activity ( $p$ trend=0.037). Adapted from reference [57].

analysis [126] of results obtained in a large French postmenopausal women-cohort study initiated in 1990 to identify most frequent cancer-associated risk factors [127]. In short, no association was found between fracture risk and either total protein (from animal or vegetable sources) or Ca intake [126]. However, further cross-tabulation analysis that subdivided the population in four subgroups revealed a slightly but significant increased risk when the highest quartile of protein intake was combined with the lowest quartile of Ca intake [126]. Of note, in this population of relatively young postmenopausal women, the daily protein intake was normal to high (mean about $1.45 \mathrm{~g} / \mathrm{kg} /$ day) and the Ca intake fairly high (mean about $1045 \mathrm{mg} /$ day) [126]. Therefore, this epidemiological study is not relevant to elderly women at risk of undernutrition as observed in hip fracture patients [13]. In another relatively young cohort aged from 35 to 59 years, the "Nurses' Health Study", a trend for hip fracture incidence inversely related to protein intake was found [128]. In the same prospective epidemiological study, however, forearm fracture incidence was slightly increased [relative risk $(\mathrm{RR})=1.18,95 \%$ confidence interval (CI), 1.01-1.38] in the highest (>95 g/day) 
as compared to the lowest ( $<68 \mathrm{~g} /$ day) quintile of ageadjusted total protein intake [128]. The reason for this skeletal site difference in the recorded association might be related to physical activity and mode of falling that differs for hip vs. forearm fracture [78]. In contrast to the French study discussed above [126], as well as to a retrospective Norwegian survey [129], no significant relation in the $\mathrm{Ca} /$ protein ratio was found with either hip or forearm fracture incidence in the "Nurses' Health Study" [128].

\section{Meta-analysis of protein intake, aBMD or BMC, and hip fracture}

Studies reported from 1966 to 2008 on the relation between protein and bone integrity in healthy human adults were systematically reviewed and meta-analyzed [130]. From the 18 studies that could be quantitatively analyzed, a significant positive pooled correlation was computed between protein intake and aBMD or BMC measured at the main clinically relevant skeletal sites [130]. Four suitable hip fracture studies [57, 128, 129, 131] were also meta-analyzed [130]. In contrast to cross-cultural ecologic studies mentioned above [121, 122], no negative association was found between the relative risk of hip fracture and the protein intake [130]. In relation with protein undernutrition and fragility fractures, the risk of spinal and hip fractures was associated with low circulating levels of IGF-I [132, 133]. Furthermore, in the elderly at risk of osteoporotic fractures, marginal dietary protein intake results in loss of muscle mass, which is associated with reduced IGF-I plasma level [134]. Muscle mass and strength are important determinants of the risk and consequence of falling in elderly [119]. There is evidence that the anabolic response of muscle to dietary protein is attenuated in elderly and, consequently, the amount of protein required to enhance muscle mass is greater [37]. Several epidemiological and clinical studies point to a beneficial effect of increasing the protein intake in elderly above the current $\mathrm{RDA}$ of $0.8 \mathrm{~g} / \mathrm{kg} /$ day to approximately $1.2 \mathrm{~g} / \mathrm{kg} /$ day; short-term studies indicated beneficial effects of protein intake up to $1.6-1.8 \mathrm{~g} / \mathrm{kg} /$ day [37].

\section{Intervention study on the impact of protein repletion after hip fracture}

In a randomized, double-blind, placebo-controlled trial, oral protein supplement providing $20 \mathrm{~g}$ of casein/day during 6 months, as compared to an isocaloric supplement, was given to patients with a recent hip fracture [14]. Both protein supplemented and placebo-controlled groups were vitamin D replete and received $500 \mathrm{mg}$ of elemental Ca daily. The protein supplemented group displayed a significantly greater increase in serum IGF-I level (Figure 5A) and lessened loss of bone mineral mass at the contralateral proximal femur (Figure 5B), with a trend towards less vertebral fracture [14]. Muscle strength improved in the protein supplemented group as compared to the isocaloric placebo-controlled group [14]. Furthermore, in the protein supplemented patients, there was also an improvement
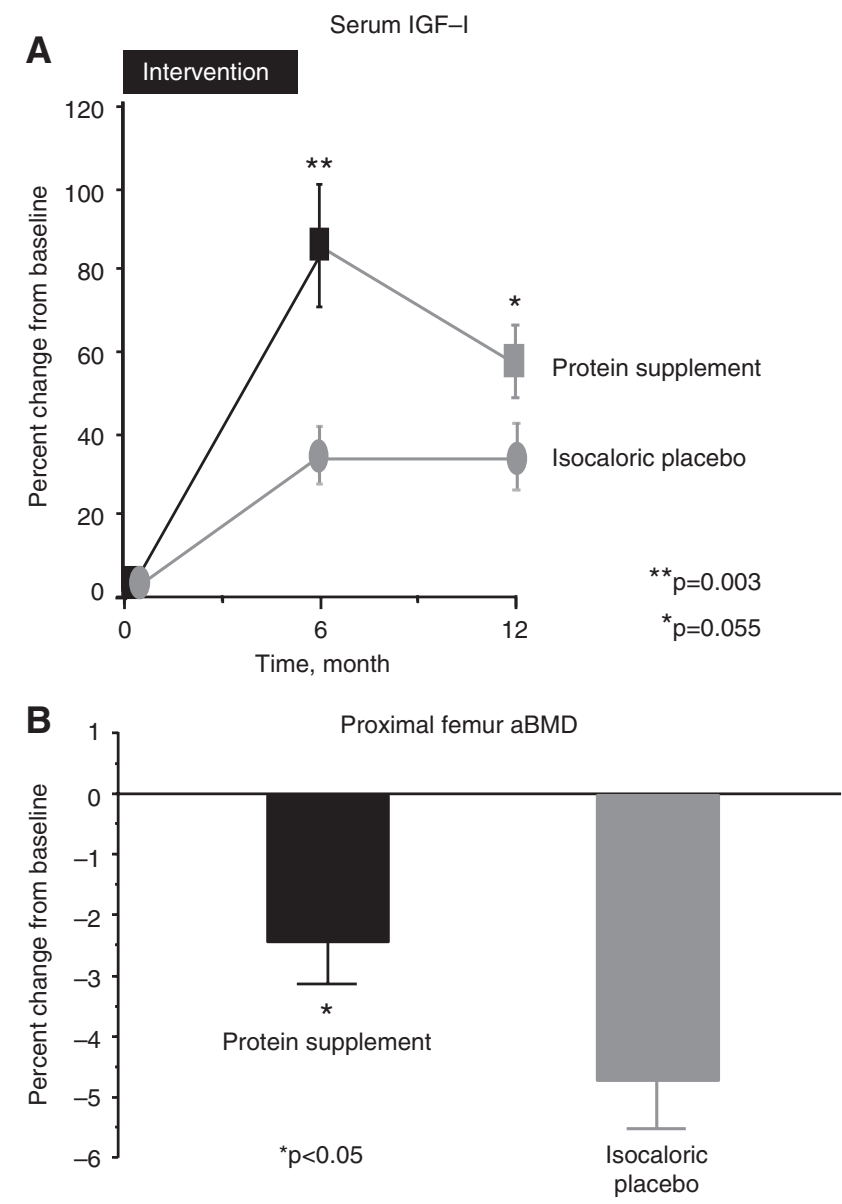

Figure 5: Effects of protein supplements on serum IGF-I and proximal femur in patients with a recent hip fracture.

The design was a 6-month, randomized, double-blind, placebo-controlled trial with 6-month post-treatment follow-up. All patients ( $n=82$, mean age $=80.7$ ) received calcium supplementation, $550 \mathrm{mg} /$ day, and one dose of vitamin D, 200,000 at baseline. They were randomized to consume either a protein (casein) supplement, $20 \mathrm{~g} /$ day or an isocaloric supplement (placebo-controls). (A) Change in serum IGF-I from baseline to the end of intervention at month 6 and follow-up at month 12. (B) Change in femoral neck aBMD from baseline to month 12 showing the significant attenuation of bone loss in the protein-supplemented group as compared to the isocaloric placebo group. Figures $A$ and $B$ are adapted from reference [14]. 
in clinical outcomes that were associated with a reduced length of stay in the rehabilitation hospital [14].

Thus, dietary protein, by impacting on both bone and skeletal muscle anabolism, plays a key role in the prevention of bone loss and sarcopenia, thus reducing the propensity to fall and the risk of fragility fractures (Figure 6).

\section{Intervention study on the impact of whey supplementation in protein-replete women}

The beneficial effect size on bone structure of nutritional interventions largely depends upon the baseline status of the tested nutrient. The highest the status of the nutrient is, the lowest the effect size is recorded. This fundamental notion should hold true not only for bone but also for in any other tissues or systems of the body. Thus, the bone effects of vitamin $\mathrm{D}$, Ca, or protein supplementation can be expected to be markedly attenuated, even abolished in replete individuals. A RCT testing a daily isocaloric whey protein supplement of $30 \mathrm{~g}$, given to healthy postmenopausal women, thus increasing the baseline protein consumption from 1.2 to $1.4 \mathrm{~g} / \mathrm{kg} /$ day, was without beneficial or detrimental effect on femoral bone structure [135]. In this study carried out in protein-replete healthy women, the increase in serum IGF-I at the end of the whey supplementation only reached $8 \%$ [135] as compared to $52 \%$ in protein-deplete hip fracture patients in whom

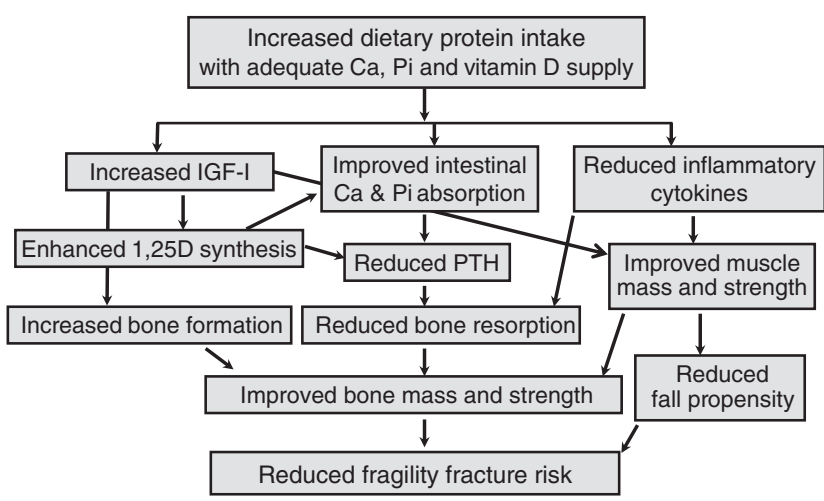

Figure 6: Positive influence of protein intake on bone and skeletal muscle health in elderly.

With aging, the impact of dietary protein on both bone and skeletal muscle anabolism plays an important role in the prevention of osteoporosis and sarcopenia. Dietary protein with calcium and vitamin $D$ contribute to attenuate both age-dependent bone loss and the propensity to fall, thereby reducing the risk of fragility fracture. Figure reproduced from reference [32]. protein supplementation significantly attenuated the post-surgical femoral neck loss as compared to isocaloric placebo [14].

\section{Concluding remarks}

In the development and maintenance of bone structures resistant to usual mechanical stresses, adequate nutrition plays an important part. In addition to Ca associated with an adequate supply of vitamin $\mathrm{D}$, dietary protein represents a key nutrient for bone health and thereby for the prevention of osteoporosis. During growth, protein undernutrition from infancy to childhood and adolescence results in reduced bone mass and strength, thereby increasing the risk of fragility fracture in later life. On the contrary, high protein intake, particularly when associated with physical activity, favors healthy bone mass acquisition. There is a positive interaction between dietary protein, Ca-Pi economy, and bone metabolism. This interaction appears to be mediated by the anabolic bone trophic factor IGF-I, the hepatic production of which is stimulated by dietary proteins. Amino acids such as arginine can exert a direct positive effect on the IGF-I production by bone-forming cells. In young adulthood, ED, as observed in anorexia nervosa, can be associated with insufficient protein supply, low circulating IGF-I, bone loss, and increased risk of fragility fracture. With aging, the reduction in the protein intake is associated in both genders with a decrease in the serum level of IGF-I, lower femoral neck aBMD, and poor physical performance. Protein undernutrition is often present in patients experiencing hip fracture. Furthermore, clinical outcome after hip fracture can be significantly improved by normalizing protein intake, which is associated with a rise in the serum IGF-I level. Thus, dietary protein contributes to bone health from early childhood to old age and thus is a key nutrient in the prevention of osteoporosis.

Acknowledgments: The author of this report is indebted to his colleagues from the Division of Bone Diseases of the University Hospitals and Faculty of Medicine, Geneva, Switzerland, who are co-authors for having actively collaborated to the following quoted papers: original studies, references $11-15,28,58,67,73,77,79,81,105$; reviews, references $10,33,72,96,119$.

Conflict of interest statement: The author has no conflict of interest with neither the concepts nor the data presented in this report. 


\section{References}

1. Froesch ER, Buergi H, Ramseier EB, Bally P, Labhart A. Antibodysuppressible and nonsuppressible insulin-like activities in human serum and their physiologic significance. an insulin assay with adipose tissue of increased precision and specificity. J Clin Invest 1963;42:1816-34.

2. Isley WL, Underwood LE, Clemmons DR. Dietary components that regulate serum somatomedin-C concentrations in humans. J Clin Invest 1983;71:175-82.

3. Clemmons DR, Seek MM, Underwood LE. Supplemental essential amino acids augment the somatomedin-C/insulin-like growth factor I response to refeeding after fasting. Metabolism 1985;34:391-5.

4. Clemmons DR, Underwood LE, Dickerson RN, Brown RO, Hak LJ, MacPhee RD, Heizer WD. Use of plasma somatomedin-C/insulinlike growth factor I measurements to monitor the response to nutritional repletion in malnourished patients. Am J Clin Nutr 1985;41:191-8.

5. Salmon WD, Jr., Daughaday WH. A hormonally controlled serum factor which stimulates sulfate incorporation by cartilage in vitro. J Lab Clin Med 1957;49:825-36.

6. Daughaday WH, Hall K, Raben MS, Salmon WD, Jr., van den Brande JL, van Wyk JJ. Somatomedin: proposed designation for sulphation factor. Nature 1972;235:107.

7. Hintz RL, Rinderknecht E. Somatomedin-C shares the carboxyterminal antigenic determinants with insulin-like growth factor-I. J Clin Endocrinol Metab 1980;51:672-3.

8. Van Wyk JJ, Svoboda ME, Underwood LE. Evidence from radioligand assays that somatomedin-C and insulin-like growth factor-I are similar to each other and different from other somatomedins. J Clin Endocrinol Metab 1980;50:206-8.

9. Frost RA, Lang CH. Regulation of insulin-like growth factorI in skeletal muscle and muscle cells. Minerva Endocrinol 2003;28:53-73.

10. Bonjour JP, Schurch MA, Chevalley T, Ammann P, Rizzoli R. Protein intake, IGF-1 and osteoporosis. Osteoporos Int 1997;7(Suppl 3):S36-42.

11. Ammann P, Bourrin S, Bonjour JP, Meyer JM, Rizzoli R. Protein undernutrition-induced bone loss is associated with decreased IGF-I levels and estrogen deficiency. J Bone Miner Res 2000;15:683-90.

12. Bourrin S, Ammann P, Bonjour JP, Rizzoli R. Dietary protein restriction lowers plasma insulin-like growth factor I (IGF-I), impairs cortical bone formation, and induces osteoblastic resistance to IGF-I in adult female rats. Endocrinology 2000;141:3149-55.

13. Delmi M, Rapin CH, Bengoa JM, Delmas PD, Vasey H, Bonjour JP. Dietary supplementation in elderly patients with fractured neck of the femur. Lancet 1990;335:1013-6.

14. Schurch MA, Rizzoli R, Slosman D, Vadas L, Vergnaud P, Bonjour JP. Protein supplements increase serum insulin-like growth factor-I levels and attenuate proximal femur bone loss in patients with recent hip fracture. A randomized, double-blind, placebo-controlled trial. Ann Intern Med 1998;128:801-9.

15. Tkatch L, Rapin CH, Rizzoli R, Slosman D, Nydegger V, Vasey H, Bonjour JP. Benefits of oral protein supplementation in elderly patients with fracture of the proximal femur. J Am Coll Nutr 1992;11:519-25.
16. Diem K, Lentner C. Tables scientifiques (ed) 1972 Ciba-Geigy SA, Basel Switzerland.

17. Forbes RM, Cooper AR, Mitchell HH. The composition of the adult human body as determined by chemical analysis. J Biol Chem 1953;203:359-66.

18. Boskey AL, Robey PG The composition of bone. In: Rosen CJ, editor. Primer on the metabolic bone diseases and disorders of mineral metabolism, 8th ed. Washington, DC: The American Society of Bone and Mineral Research, Wiley-Blackwell, 2013:49-58.

19. Kraenzlin ME, Seibel MJ. Measurements of biochemical markers of bone resorption. In: Seibel MJ, Robins SP, Bilezikian JP, editors. Dynamic bone and cartilage metabolism: principles and clinical applications, 2nd ed. San Diego: Academic Press, 2006: 541-63.

20. Vasikaran S, Eastell R, Bruyere O, Foldes AJ, Garnero P, Griesmacher A, McClung M, Morris HA, Silverman S, Trenti T, Wahl DA, Cooper C, Kanis JA. Markers of bone turnover for the prediction of fracture risk and monitoring of osteoporosis treatment: a need for international reference standards. Osteoporos Int 2011;22:391-420.

21. Nishizawa $Y$, Ohta H, Miura M, Inaba M, Ichimura S, Shiraki $M$, Takada J, Chaki O, Hagino H, Fujiwara S, Fukunaga M, Miki T, Yoshimura N. Guidelines for the use of bone metabolic markers in the diagnosis and treatment of osteoporosis (2012 edition). I Bone Miner Metab 2013;31:1-15.

22. Adamo ML, Wang L, Heron L, Ben-Yosef D, Zhao H, Le Roith D. Overview and molecular aspects of the insulin-like growh factor system. In: Houston MS, Holly JM, E.L. F, editors. IGF and nutrition in health and disease. Totowa, New Jersey: Humana Press, 2005:3-22.

23. Ohlsson C, Mohan S, Sjogren K, Tivesten A, Isgaard J, Isaksson O, Jansson JO, Svensson J. The role of liver-derived insulin-like growth factor-I. Endocr Rev 2009;30:494-535.

24. Thissen JP, Ketelslegers JM, Underwood LE. Nutritional regulation of the insulin-like growth factors. Endocr Rev 1994;15:80-101.

25. Liu JP, Baker J, Perkins AS, Robertson EJ, Efstratiadis A. Mice carrying null mutations of the genes encoding insulin-like growth factor I (Igf-1) and type 1 IGF receptor (Igf1r). Cell 1993;75:59-72.

26. Thissen JP, Beauloye V, Ketelslegers JM, Underwood LE regulation of insulin-like growth factor-I by nutrition. In: Houston MS, Holly JM, E.L. F, editors. IGF and nutrition in health and disease. Totowa, New Jersey: Humana Press, 2005:25-52.

27. Thissen JP, Underwood LE, Maiter D, Maes M, Clemmons DR, Ketelslegers JM. Failure of insulin-like growth factor-I (IGF-I) infusion to promote growth in protein-restricted rats despite normalization of serum IGF-I concentrations. Endocrinology 1991;128:885-90.

28. Caverzasio J, Montessuit C, Bonjour JP. Stimulatory effect of insulin-like growth factor-1 on renal Pi transport and plasma 1,25-dihydroxyvitamin D3. Endocrinology 1990;127:453-9.

29. Nesbitt T, Drezner MK. Insulin-like growth factor-I regulation of renal 25-hydroxyvitamin D-1-hydroxylase activity. Endocrinology 1993;132:133-8.

30. Condamine L, Menaa C, Vrtovsnik F, Friedlander G, Garabedian M. Local action of phosphate depletion and insulin-like growth factor 1 on in vitro production of 1,25-dihydroxyvitamin $D$ by cultured mammalian kidney cells. J Clin Invest 1994;94:1673-9. 
31. Menaa C, Vrtovsnik F, Friedlander G, Corvol M, Garabedian M. Insulin-like growth factor I, a unique calcium-dependent stimulator of 1,25-dihydroxyvitamin D3 production. Studies in cultured mouse kidney cells. J Biol Chem 1995;270:25461-7.

32. Bonjour JP. Protein intake and bone health. Int J Vitam Nutr Res 2011;81:134-42.

33. Caverzasio J, Bonjour JP. IGF-I, a key regulator of renal phosphate transport and 1,25-Dihydroxyvitamine D3 production during growth. News Physiol. Sci. 1991;6:206-10.

34. Comar CL, Nold MM, Wasserman RH. The influence of amino acids and other organic compounds on the gastrointestinal absorption of calcium 45 and strontium 89 in the rat. J Nutr 1956;59:371-83.

35. Kerstetter JE, O’Brien KO, Caseria DM, Wall DE, Insogna KL. The impact of dietary protein on calcium absorption and kinetic measures of bone turnover in women. J Clin Endocrinol Metab 2005;90:26-31.

36. Conigrave AD, Quinn SJ, Brown EM. L-amino acid sensing by the extracellular Ca2+-sensing receptor. Proc Natl Acad Sci USA 2000;97:4814-9.

37. Gaffney-Stomberg E, Insogna KL, Rodriguez NR, Kerstetter JE. Increasing dietary protein requirements in elderly people for optimal muscle and bone health. J Am Geriatr Soc 2009;57:1073-9.

38. Topala CN, Schoeber JP, Searchfield LE, Riccardi D, Hoenderop JG, Bindels RJ. Activation of the Ca2+-sensing receptor stimulates the activity of the epithelial $\mathrm{Ca} 2+$ channel TRPV5. Cell Calcium 2009;45:331-9.

39. Conigrave AD, Brown EM, Rizzoli R. Dietary protein and bone health: roles of amino acid-sensing receptors in the control of calcium metabolism and bone homeostasis. Annu Rev Nutr 2008;28:131-55.

40. Ferre S, Hoenderop JG, Bindels RJ. Sensing mechanisms involved in $\mathrm{Ca} 2+$ and Mg2+ homeostasis. Kidney Int 2012;82:1157-66.

41. Conigrave AD, Ward DT. Calcium-sensing receptor (CaSR): pharmacological properties and signaling pathways. Best Pract Res Clin Endocrinol Metab 2013;27:315-31.

42. Kerstetter JE, O’Brien KO, Insogna KL. Dietary protein, calcium metabolism, and skeletal homeostasis revisited. Am J Clin Nutr 2003;78(3 Suppl):584S-92S.

43. Fenton TR, Lyon AW, Eliasziw M, Tough SC, Hanley DA. Metaanalysis of the effect of the acid-ash hypothesis of osteoporosis on calcium balance. J Bone Miner Res 2009;24:1835-40.

44. Kerstetter JE, Caseria DM, Mitnick ME, Ellison AF, Gay LF, Liskov TA, Carpenter TO, Insogna KL. Increased circulating concentrations of parathyroid hormone in healthy, young women consuming a protein-restricted diet. Am J Clin Nutr 1997;66:1188-96.

45. Kerstetter JE, O’Brien KO, Insogna KL. Low protein intake: the impact on calcium and bone homeostasis in humans. J Nutr 2003;133:855S-61S.

46. Bonjour JP. Dietary protein: an essential nutrient for bone health. J Am Coll Nutr 2005;24(6 Suppl):526S-36S.

47. Kerstetter JE. Dietary protein and bone: a new approach to an old question. Am J Clin Nutr 2009;90:1451-2.

48. Bonjour JP. Nutritional disturbance in acid-base balance and osteoporosis: a hypothesis that disregards the essential homeostatic role of the kidney. Br J Nutr 2013;110:1168-77.

49. Roughead ZK, Johnson LK, Lykken GI, Hunt JR. Controlled high meat diets do not affect calcium retention or indices of bone status in healthy postmenopausal women. J Nutr 2003;133:1020-6.
50. Cao JJ, Johnson LK, Hunt JR. A diet high in meat protein and potential renal acid load increases fractional calcium absorption and urinary calcium excretion without affecting markers of bone resorption or formation in postmenopausal women. J Nutr 2011;141:391-7.

51. Fenton TR, Tough SC, Lyon AW, Eliasziw M, Hanley DA. Causal assessment of dietary acid load and bone disease: a systematic review \& meta-analysis applying Hill's epidemiologic criteria for causality. Nutr I 2011;10:1-23.

52. Calvez J, Poupin N, Chesneau C, Lassale C, Tome D. Protein intake, calcium balance and health consequences. Eur J Clin Nutr 2012;66:281-95.

53. Hanley DA, Whiting SJ. Does a high dietary Acid content cause bone loss, and can bone loss be prevented with an alkaline diet? J Clin Densitom 2013;16:420-5.

54. Fenton TR, Eliasziw M, Tough SC, Lyon AW, Brown JP, Hanley DA. Low urine $\mathrm{pH}$ and acid excretion do not predict bone fractures or the loss of bone mineral density: a prospective cohort study. BMC Musculoskelet Disord 2010;11:88.

55. McLean RR, Qiao N, Broe KE, Tucker KL, Casey V, Cupples LA, Kiel DP, Hannan MT. Dietary acid load is not associated with lower bone mineral density except in older men. J Nutr 2011;141:588-94.

56. Rouy E, Vico L, Laroche N, Benoit V, Rousseau B, Blachier F, Tome D, Blais A. Protein quality affects bone status during moderate protein restriction in growing mice. Bone 2014;59:7-13.

57. Munger RG, Cerhan JR, Chiu BC. Prospective study of dietary protein intake and risk of hip fracture in postmenopausal women. Am J Clin Nutr 1999;69:147-52.

58. Chevalley T, Rizzoli R, Manen D, Caverzasio J, Bonjour JP. Arginine increases insulin-like growth factor-I production and collagen synthesis in osteoblast-like cells. Bone 1998;23:103-9.

59. Bikle DD, Wang Y. Insulin like growth factor-I: a critical mediator of the skeletal response to parathyroid hormone. Curr Mol Pharmacol 2012;5:135-42.

60. Neer RM, Arnaud CD, Zanchetta JR, Prince R, Gaich GA, Reginster JY, Hodsman AB, Eriksen EF, Ish-Shalom S, Genant HK, Wang O, Mitlak BH. Effect of parathyroid hormone (1-34) on fractures and bone mineral density in postmenopausal women with osteoporosis. N Engl J Med 2001;344:1434-41.

61. Bonjour JP, Chevalley T, Ferrari S, Rizzoli R Peak bone mass and its regulation In: Glorieux FH, Pettifor FM, Jüppner $\mathrm{H}$, editors. Pediatric bone, 2nd ed. Amsterdam: Elsevier Inc, 2012:189-221.

62. Parfitt AM. The two faces of growth: benefits and risks to bone integrity. Osteoporos Int 1994;4:382-98.

63. Garn SM, Rohmann CG, Behar M, Viteri F, Guzman MA. Compact bone deficiency in protein-calorie malnutrition. Science 1964;145:1444-5.

64. Thissen JP, Triest S, Maes M, Underwood LE, Ketelslegers JM. The decreased plasma concentration of insulin-like growth factor-I in protein-restricted rats is not due to decreased numbers of growth hormone receptors on isolated hepatocytes. J Endocrinol 1990;124:159-65.

65. Bala RM, Lopatka J, Leung A, McCoy E, McArthur RG. Serum immunoreactive somatomedin levels in normal adults, pregnant women at term, children at various ages, and children with constitutionally delayed growth. J Clin Endocrinol Metab 1981;52:508-12. 
66. Tanner JM, Whitehouse RH. Clinical longitudinal standards for height, weight, height velocity, weight velocity, and stages of puberty. Arch Dis Child 1976;51:170-9.

67. Theintz G, Buchs B, Rizzoli R, Slosman D, Clavien H, Sizonenko PC, Bonjour JP. Longitudinal monitoring of bone mass accumulation in healthy adolescents: evidence for a marked reduction after 16 years of age at the levels of lumbar spine and femoral neck in female subjects. J Clin Endocrinol Metab 1992;75:1060-5.

68. Breen ME, Laing EM, Hall DB, Hausman DB, Taylor RG, Isales CM, Ding KH, Pollock NK, Hamrick MW, Baile CA, Lewis RD. 25-hydroxyvitamin D, insulin-like growth factor-I, and bone mineral accrual during growth. J Clin Endocrinol Metab 2011;96:E89-98.

69. Laron Z. Insulin-like growth factor-I treatment of children with Laron syndrome (primary growth hormone insensitivity). Pediatr Endocrinol Rev 2008;5:766-71.

70. Giustina A, Mazziotti G, Canalis E. Growth hormone, insulin-like growth factors, and the skeleton. Endocr.Rev. 2008;29:535-59.

71. Savage MO. Phenotypes, investigation and treatment of primary IGF-1 deficiency. Endocr Dev 2013;24:138-49.

72. Bonjour JP, Chevalley T, Rizzoli R, Ferrari S. Gene-environment interactions in the skeletal response to nutrition and exercise during growth. Med Sport Sci 2007;51:64-80.

73. Clavien H, Theintz G, Rizzoli R, Bonjour JP. Does puberty alter dietary habits in adolescents living in a western society? J Adolesc Health 1996;19:68-75.

74. Daly RM. The effect of exercise on bone mass and structural geometry during growth. Med Sport Sci 2007;51:33-49.

75. Specker B, Binkley T. Randomized trial of physical activity and calcium supplementation on bone mineral content in 3- to 5-year-old children. J Bone Miner Res 2003;18:885-92.

76. Alexy U, Remer T, Manz F, Neu CM, Schoenau E. Long-term protein intake and dietary potential renal acid load are associated with bone modeling and remodeling at the proximal radius in healthy children. Am J Clin Nutr 2005;82:1107-14.

77. Chevalley T, Bonjour JP, Ferrari S, Rizzoli R. High-protein intake enhances the positive impact of physical activity on BMC in prepubertal boys. J Bone Miner Res 2008;23:131-42.

78. Bouxsein ML Biomechanics of age-related fractures. In: Marcus R, Feldman D, Kelsey J, editors. Osteoporosis, vol. 1. San Diego: Academic Press, 2001:509-34.

79. Chevalley T, Bonjour JP, van Rietbergen B, Ferrari S, Rizzoli R. Tracking of environmental determinants of bone structure and strength development in healthy boys: an eight-year follow up study on the positive interaction between physical activity and protein intake from prepuberty to mid-late adolescence. J Bone Miner Res 2014;29:2182-92.

80. Cooper C, Atkinson EJ, Hensrud DD, Wahner HW, O'Fallon WM, Riggs BL, Melton LJ, 3rd. Dietary protein intake and bone mass in women. Calcif Tissue Int 1996;58:320-5.

81. Gremion G, Rizzoli R, Slosman D, Theintz G, Bonjour JP. Oligoamenorrheic long-distance runners may lose more bone in spine than in femur. Med Sci Sports Exerc 2001;33:15-21.

82. Warren MP, Brooks-Gunn J, Fox RP, Holderness CC, Hyle EP, Hamilton WG. Osteopenia in exercise-associated amenorrhea using ballet dancers as a model: a longitudinal study. J Clin Endocrinol Metab 2002;87:3162-8.
83. Yeager KK, Agostini R, Nattiv A, Drinkwater B. The female athlete triad: disordered eating, amenorrhea, osteoporosis. Med Sci Sports Exerc 1993;25:775-7.

84. Nattiv A, Loucks AB, Manore MM, Sanborn CF, Sundgot-Borgen J, Warren MP. American College of Sports Medicine position stand. The female athlete triad. Med Sci Sports Exerc 2007;39:1867-82.

85. Misra M, Klibanski A. The neuroendocrine basis of anorexia nervosa and its impact on bone metabolism. Neuroendocrinology 2011;93:65-73.

86. Warren MP. Endocrine manifestations of eating disorders. J Clin Endocrinol Metab 2011;96:333-43.

87. Grinspoon S, Thomas E, Pitts S, Gross E, Mickley D, Miller K, Herzog D, Klibanski A. Prevalence and predictive factors for regional osteopenia in women with anorexia nervosa. Ann Intern Med 2000;133:790-4.

88. Misra M, Prabhakaran R, Miller KK, Goldstein MA, Mickley D, Clauss L, Lockhart P, Cord J, Herzog DB, Katzman DK, Klibanski A. Weight gain and restoration of menses as predictors of bone mineral density change in adolescent girls with anorexia nervosa-1. J Clin Endocrinol Metab 2008;93:1231-7.

89. Livingstone C. Insulin-like growth factor-I (IGF-I) and clinical nutrition. Clin Sci (Lond) 2013;125:265-80.

90. Misra M, Prabhakaran R, Miller KK, Goldstein MA, Mickley D, Clauss L, Lockhart P, Cord J, Herzog DB, Katzman DK, Klibanski A. Prognostic indicators of changes in bone density measures in adolescent girls with anorexia nervosa-II. J Clin Endocrinol Metab 2008;93:1292-7.

91. Soyka LA, Misra M, Frenchman A, Miller KK, Grinspoon S, Schoenfeld DA, Klibanski A. Abnormal bone mineral accrual in adolescent girls with anorexia nervosa. J Clin Endocrinol Metab 2002;87:4177-85.

92. Schebendach JE, Porter KJ, Wolper C, Walsh BT, Mayer LE. Accuracy of self-reported energy intake in weight-restored patients with anorexia nervosa compared with obese and normal weight individuals. Int J Eat Disord 2012;45:570-4.

93. Huas C, Godart N, Foulon C, Pham-Scottez A, Divac S, Fedorowicz V, Peyracque E, Dardennes R, Falissard B, Rouillon F. Predictors of dropout from inpatient treatment for anorexia nervosa: data from a large French sample. Psychiatry Res 2011;185:421-6.

94. Kohl M, Foulon C, Guelfi JD. [Hyperactivity and anorexia nervosa: behavioural and biological perspective]. Encephale 2004;30:492-9.

95. Russell JD, Mira M, Allen BJ, Stewart PM, Vizzard J, Arthur B, Beumont PJ. Protein repletion and treatment in anorexia nervosa. Am J Clin Nutr 1994;59:98-102.

96. Bonjour JP, Chevalley T. Pubertal timing, bone acquisition, and risk of fracture throughout life. Endocr Rev 2014;35:820-47.

97. Misra M, Klibanski A. Endocrine consequences of anorexia nervosa. Lancet Diabetes Endocrinol 2014;2:581-92.

98. Cao JJ, Pasiakos SM, Margolis LM, Sauter ER, Whigham LD, McClung JP, Young AJ, Combs GF, Jr. Calcium homeostasis and bone metabolic responses to high-protein diets during energy deficit in healthy young adults: a randomized controlled trial. Am J Clin Nutr 2014;99:400-7.

99. Cosman F, Ruffing J, Zion M, Uhorchak J, Ralston S, Tendy S, McGuigan FE, Lindsay R, Nieves J. Determinants of stress fracture risk in United States Military Academy cadets. Bone 2013;55:359-66. 
100. Shapses SA, Riedt CS. Bone, body weight, and weight reduction: what are the concerns? J Nutr 2006;136: 1453-6.

101. Shapses SA, Sukumar D. Bone metabolism in obesity and weight loss. Annu Rev Nutr 2012;32:287-309.

102. Sukumar D, Ambia-Sobhan H, Zurfluh R, Schlussel Y, Stahl TJ, Gordon CL, Shapses SA. Areal and volumetric bone mineral density and geometry at two levels of protein intake during caloric restriction: a randomized, controlled trial. J Bone Miner Res 2011;26:1339-48.

103. Metz JA, Anderson JJ, Gallagher PN, Jr. Intakes of calcium, phosphorus, and protein, and physical-activity level are related to radial bone mass in young adult women. Am J Clin Nutr 1993;58:537-42.

104. Hannan MT, Tucker KL, Dawson-Hughes B, Cupples LA, Felson DT, Kiel DP. Effect of dietary protein on bone loss in elderly men and women: the Framingham Osteoporosis Study. J Bone Miner Res 2000;15:2504-12.

105. Geinoz G, Rapin CH, Rizzoli R, Kraemer R, Buchs B, Slosman D, Michel JP, Bonjour JP. Relationship between bone mineral density and dietary intakes in the elderly. Osteoporos Int 1993;3:242-8.

106. Bartali B, Salvini S, Turrini A, Lauretani F, Russo CR, Corsi AM, Bandinelli S, D’Amicis A, Palli D, Guralnik JM, Ferrucci L. Age and disability affect dietary intake. J Nutr 2003;133:2868-73.

107. Lewitt MS, Hall $K$ The Insulin growth factor system and nutrition in adulthood and aging. In: Houston MS, Holly JM, Feldman EL, editors. IGF and nutrition in health and disease. Totowa, NJ: Humana Press, 2005:157-74.

108. Wolfe RR, Miller SL, Miller KB. Optimal protein intake in the elderly. Clin Nutr 2008;27:675-84.

109. Elango R, Humayun MA, Ball RO, Pencharz PB. Evidence that protein requirements have been significantly underestimated. Curr Opin Clin Nutr Metab Care 2010;13:52-7.

110. Heaney RP. Calcium, dairy products and osteoporosis. J Am Coll Nutr 2000;19(2 Suppl):83S-99S.

111. Bell J, Whiting SJ. Elderly women need dietary protein to maintain bone mass. Nutr Rev 2002;60:337-41.

112. Dawson-Hughes B, Harris SS. Calcium intake influences the association of protein intake with rates of bone loss in elderly men and women. Am J Clin Nutr 2002;75:773-9.

113. Mangano KM, Sahni S, Kerstetter JE. Dietary protein is beneficial to bone health under conditions of adequate calcium intake: an update on clinical research. Curr Opin Clin Nutr Metab Care 2014;17:69-74.

114. Dawson-Hughes B, Harris SS, Rasmussen H, Song L, Dallal GE. Effect of dietary protein supplements on calcium excretion in healthy older men and women. J Clin Endocrinol Metab 2004;89:1169-73.

115. Samieri C, Ginder Coupez V, Lorrain S, Letenneur L, Alles B, Feart C, Paineau D, Barberger-Gateau P. Nutrient patterns and risk of fracture in older subjects: results from the Three-City Study. Osteoporos Int 2013;24:1295-305.

116. Langsetmo L, Barr SI, Berger C, Kreiger N, Rahme E, Adachi JD, Papaioannou A, Kaiser SM, Prior JC, Hanley DA, Kovacs CS, Josse RG, Goltzman D. Associations of protein intake and protein source with bone mineral density and fracture risk: a population-based cohort study. J Nutr Health Aging 2015;19:861-8.
117. Larocque SC, Kerstetter JE, Cauley JA, Insogna KL, Ensrud K, Lui LY, Allore HG. dietary protein and vitamin D intake and risk of falls: a secondary analysis of postmenopausal women from the study of osteoporotic fractures. J Nutr Gerontol Geriatr 2015;34:305-18.

118. McCarty MF, DiNicolantonio JJ. An increased need for dietary cysteine in support of glutathione synthesis may underlie the increased risk for mortality associated with low protein intake in the elderly. Age (Dordr) 2015;37:96.

119. Bonjour JP, Schurch MA, Rizzoli R. Nutritional aspects of hip fractures. Bone 1996;18(3 Suppl):139S-44S.

120. Tosteson AN, Gottlieb DJ, Radley DC, Fisher ES, Melton LJ, 3rd. Excess mortality following hip fracture: the role of underlying health status. Osteoporos Int 2007;18:1463-72.

121. Abelow BJ, Holford TR, Insogna KL. Cross-cultural association between dietary animal protein and hip fracture: a hypothesis. Calcif Tissue Int 1992;50:14-8.

122. Frassetto LA, Todd KM, Morris RC, Jr., Sebastian A. Worldwide incidence of hip fracture in elderly women: relation to consumption of animal and vegetable foods. J Gerontol A Biol Sci Med Sci 2000;55:M585-92.

123. Abellan van Kan G, Gambassi G, de Groot LC, Andrieu S, Cederholm T, Andre E, Caubere JP, Bonjour JP, Ritz P, Salva A, Sinclair A, Vellas B, Dayde J, Deregnaucourt J, Latge C. Nutrition and aging. The Carla Workshop. J Nutr Health Aging 2008;12:355-64.

124. De Laet C, Kanis JA, Oden A, Johanson H, Johnell O, Delmas P, Eisman JA, Kroger H, Fujiwara S, Garnero P, McCloskey EV, Mellstrom D, Melton LJ, 3rd, Meunier PJ, Pols HA, Reeve J, Silman A, Tenenhouse A. Body mass index as a predictor of fracture risk: a meta-analysis. Osteoporos Int 2005;16:1330-8.

125. Wengreen HJ, Munger RG, West NA, Cutler DR, Corcoran CD, Zhang J, Sassano NE. Dietary protein intake and risk of osteoporotic hip fracture in elderly residents of Utah. J Bone Miner Res 2004;19:537-45.

126. Dargent-Molina P, Sabia S, Touvier M, Kesse E, Breart G, Clavel-Chapelon F, Boutron-Ruault MC. Proteins, dietary acid load, and calcium and risk of postmenopausal fractures in the E3N French women prospective study. J Bone Miner Res 2008;23:1915-22.

127. Clavel-Chapelon F, van Liere MJ, Giubout C, Niravong MY, Goulard H, Le Corre C, Hoang LA, Amoyel J, Auquier A, Duquesnel E. E3N, a French cohort study on cancer risk factors. E3N Group. Etude Epidemiologique aupres de femmes de l'Education Nationale. Eur J Cancer Prev 1997;6:473-8.

128. Feskanich D, Willett WC, Stampfer MJ, Colditz GA. Protein consumption and bone fractures in women. Am J Epidemiol 1996;143:472-9.

129. Meyer HE, Pedersen JI, Loken EB, Tverdal A. Dietary factors and the incidence of hip fracture in middle-aged Norwegians. A prospective study. Am J Epidemiol 1997;145:117-23.

130. Darling AL, Millward DJ, Torgerson DJ, Hewitt CE, Lanham-New SA. Dietary protein and bone health: a systematic review and meta-analysis. Am J Clin Nutr 2009;90:1674-92.

131. Mussolino ME, Looker AC, Madans JH, Langlois JA, Orwoll ES. Risk factors for hip fracture in white men: the NHANES I Epidemiologic Follow-up Study. J Bone Miner Res 1998;13:918-24.

132. Sugimoto T, Nishiyama K, Kuribayashi F, Chihara K. Serum levels of insulin-like growth factor (IGF) I, IGF-binding 
protein (IGFBP)-2, and IGFBP-3 in osteoporotic patients with and without spinal fractures. J Bone Miner Res 1997;12:1272-9.

133. Garnero P, Sornay-Rendu E, Delmas PD. Low serum IGF-1 and occurrence of osteoporotic fractures in postmenopausal women. Lancet 2000;355:898-9.

134. Castaneda C, Gordon PL, Fielding RA, Evans WJ, Crim MC. Marginal protein intake results in reduced plasma IGF-I levels and skeletal muscle fiber atrophy in elderly women. J Nutr Health Aging 2000;4:85-90.

135. Zhu K, Meng X, Kerr DA, Devine A, Solah V, Binns CW, Prince RL. The effects of a two-year randomized, controlled trial of whey protein supplementation on bone structure, IGF-1, and urinary calcium excretion in older postmenopausal women. J Bone Miner Res 2011;26:2298-306. 